\title{
Thermal and photo-oxidative degradation of secondary polypropylene filled with aluminosilicate microspheres
}

\author{
(C) Marina V. Bazunova ${ }^{+}$, Arthur A. Psyanchi, Elena M. Zakharova, \\ Ainur R. Sadretdinov, Aigiz G. Khusnullin, and Vadim P. Zakharov* \\ Department of Macromolecular Compounds and General Chemical Technology. Chemical faculty. \\ Bashkir State University. Zaki Validi St., 32. Ufa, 450076. Republic of Bashkortostan. Russia. \\ Phone:+7 (347)229-97-24. E-mail:mbazunova@mail.ru
}

\section{*Supervising author; ${ }^{+}$Corresponding author}

Keywords: secondary polypropylene, silica-alumina microspheres, the thermal stability, degradation, filling, composite material.

This article describes the work on the study of thermal and photo-oxidative degradation of the composition of secondary polypropylene filled with aluminosilicate microspheres. As you know, the creation of composites based on a polymer matrix filled with various substances is a good method for regulating the performance properties of the material. Inorganic fillers are of great interest and have better mechanical and thermal properties, thus have the potential to improve the mechanical and thermal properties of composites compared to matrix polymers. A promising inorganic filler is an alumosilicate microsphere. Interest in the use of ash microspheres as a filler is due to the presence of such qualities as chemical resistance, low density, high strength and low cost. The most important characteristic of the additive is to ensure thermal stability in the processing processes and when compounding with a polymer. In connection with the above, the aim of this work is to study the thermophysical parameters of polymer composites based on polypropylene filled with particles of aluminosilicate microspheres and to study the influence of ash microspheres on the laws of thermal and photo - oxidative degradation of the polymer phase. In this work, when creating a polymer composite, secondary polypropylene was used, which is a crushed material from substandard plastic products produced by injection molding. Studies of the thermophysical properties of polymer samples were carried out on the device TGA-DSC1. Thermooxidation degradation of polymer composites was performed during thermal exposure in the air at temperatures of 150,175 and $200{ }^{\circ} \mathrm{C}$. Photo-oxidative degradation was performed by exposing the samples under UV irradiation in the air at temperatures of 40,60 and $90{ }^{\circ} \mathrm{C}$.

During the work, it was found that the introduction of an aluminosilicate microsphere into polypropylene has virtually no effect on changes in the melting and crystallization temperatures of the polymer phase. The presence of an aluminosilicate microsphere increases the degree of accumulation of carbonyl compounds in the polymer phase during thermal and photo-oxidative degradation.

\section{References}

[1] Al.Al. Berlin, S.A. Wolfson, Oshmyan V.G., N.S. Enikolopov. Principles of creating composite polymer materials. Moscow: Chemistry. 1990. 179p. (russian)

[2] T.N. Teryaeva, O.V. Kostenko, Z.R. Ismagilov, N.V. Shikina, N.A. Rudina, V.A. Antipova. Physical and chemical properties of aluminosilicate hollow microspheres. Bulletin of the Kuzbass state technical University. 2013. No.5(99). P.86-90. (russian)

[3] L.D. Danilin, V.S. Drozhzhin, M.D. Kuvaev, S.A. Kulikov, N.V. Maksimova, V.I. Malinov, I.V. Pikulin, S.A. Redyushev, A.N. Khovrin. Hollow microspheres from fly ash - a multifunctional filler of composite materials. Cement and its application. 2012. No.4. P.100-105. (russian)

[4] V.E. Samorokov, E.V. Zelinskaya. Use of microspheres in composite materials. Irstu Bulletin. 2012. Vol.68. No.9. P.201-205. (russian)

[5] L.P. Varlamova, V.A. Izvozchikova, S.A. Ryabov, A.S. Averchenko, Yu.D. Semchikov. Influence of aluminosilicate microspheres on physical-mechanical and rheological properties of rigid polyurethane foams. Journal of applied chemistry. 2008. Vol.81. No.3. P.502-504. (russian) 
THERMAL AND PHOTO-OXIDATIVE DEGRADATION OF SECONDARY POLYPROPYLENE FILLED WITH... 28-35

[6] V.S. Soloviev, M.V. Uspenskaya, N.V. Sirotinkin. Polymer water-absorbing compositions with increased strength. Izvestia of higher education institutions. Instrument making. 2010. Vol.53. No.4. P.63-65. (russian)

[7] V.F. Kablov, O.M. Novopol'tseva, V.G. Kochetkov, V.V. Pudovkin. Physicomechanical, Thermal, and Flame-Retardant Properties of Elastomer Compounds Based on Ethylene-Propylene-Diene Rubber and Filled with Hollow Aluminosilicate Microspheres. Russian Journal of Applied Chemistry. 2017. Vol.90. No.2. P.257-261.

[8] M.A. Abdullah, A. Mohamad, C. Ranganathaiah, B. Siddramaiah. Positron Lifetime Spectroscopy and Differential Scanning Calorimetric Study of Polystyrene-Based Composites with Fly Ash, Cenospheres, and Calcium Aluminosilicate as Fillers. Journal of Applied Polymer Science. 2010. Vol.116. P.3087-3094.

[9] K. Majeed, R. Arjmandi, M.A. Al-Maadeed, A. Hassan, Z. Ali, A.U. Khan, M.S. Khurram, I.M. Inuwa, P.N. Khanam. Structural properties of rice husk and its polymer matrix composites: An overview. Lignocellulosic fibre and biomass-based composite materials: processing, properties and applications. Woodhead Publishing Series in Composites Science and Engineering. 2017. P.473-490.

[10] N. Raghu, K. Amey, C. Shakti, K.A. Pankaj. Rice husk reinforced polypropylene composites: mechanical, morphological and thermal properties. Journal of the Indian Academy of Wood Science. 2018. Vol.15. No.1. P.96-104.

[11] O.O. Berlinda, G.McD. Armando. Evaluation of the Mechanical, Thermal and Rheological Properties of Recycled Polyolefins Rice-Hull Composites. Materials. 2020. Vol.13. No.3. P.667.

[12] R.B. Salikhov, M.V. Bazunova, A.A. Bazunova, T.R. Salikhov, V.P. Zakharov. Study of thermal properties of biodegradable composite materials based on recycled polypropylene. Letters on Materials. 2018. Vol.8. No.4. P.512-515.

[13] V.P. Zakharov, A.G. Kusnullin, E.M. Zakharova, A.S. Shurshina, E.I. Kulish. Preparation of blending compositions based on secondary polypropylene with controlled physico-mechanical properties.

Periódico Tchê Química. 2019. Vol.16. No.32. P.139-146.

[14] R.K. Fakhretdinov, L.R. Galiev, A.R. Mingazova, V.P. Zakharov. Processing of polymer composites based on secondary polypropylene by injection molding. Structures made of composite materials. 2017. No.3(147). P.14-18. (russian)

[15] Yu.S. Lipatov. Physical and chemical bases of polymer filling. Moscow: Chemistry. 1991. 245 p. (russian)

[16] O.F. Shlensky, E.B. Krentzel, I.H. Musyaev. Influence of structure and molecular mobility of polyolefins on their thermal stability. Plastic masses. 1999. No.3. P.12-18. (russian)

[17] T.N. Teryaeva, O.V. Kasyanova, T.V. Lopatina. Thermophysical properties of plastics on the basis of polypropylene and ochre. Bulletin of the Kuzbass state technical University. 2005. No.4(1). P.69-73. (russian)

[18] L.I. Chumadova, M.Yu. Skorikov, T.G. Stepanyan, M.V. Morozov, D.M. Vestnikov. Thermal characteristics of liquid ceramic thermal insulation material based on aluminosilicate and sodiumborosilicate microspheres. Modern scientific research and innovation. 2016. No.1. [Electronic resource]. URL: http://web.snauka.ru/issues/2016/01/62263 